\title{
The Truth of College Ideological and Political Education
}

\author{
Liang Gao \\ Tianfu college of swufE, Mianyang, Sichuan, 621000
}

Keywords: Truth, College Ideological and Political Education, Student Management

\begin{abstract}
Ideological and political education is to educate the educators to establish a correct world outlook, values, outlook on life and ways of thinking of education, is to educate people on the correct ideas and ideas and methods. The quality of ideological and political education in colleges and universities to enhance the quality of many factors, the impact of varying degrees. The content of ideological and political education is based on certain social requirements and the ideological practice of the educated. After the educator selects the design, the content of ideology and politics is purposefully and systematically delivered to the educated's ideology, values and moral norms and other information. Educational content is the object that education objects directly face, evaluate and receive. It is the carrier of the goal of ideological and political education and the fundamental factor that affects the quality of ideological and political education in colleges and universities. The influence of the contents of ideological and political education on the quality improvement of ideological and political education in colleges and universities depends mainly on its truth and credibility.
\end{abstract}

\section{Introduction}

The ideological and political education in colleges and universities is related to the cultivation of qualified personnel in colleges and universities, so as to ensure the healthy growth of colleges and universities and the successful promotion of higher education. In the day-to-day political education, the true charm and credibility of educational content can be fully reflected, and the influence of ideological and political education in colleges and universities can be effectively guaranteed.

\section{The truth of the contents of ideological and political education in colleges and universities}

Help to enhance the charm of ideological and political education in colleges and universities. Truth itself has charm, it carries people's values and spiritual pursuit. In practice, to enhance the charm of ideological and political education in colleges and universities, we must first determine the truth of educational content. Only by fully reflecting the truth charm of educational content can the influence of ideological and political education in colleges and universities be effectively guaranteed. College ideological and political education plays an important role in cultivating high-quality talents, promoting the reform and development of higher education, and maintaining the stability of schools and society. However, in practice, ideological and political education is generally not attractive enough. Some colleges and universities are not very interested in receiving ideological and political education. Ideological and political education is not sufficiently contagious. Some colleges and universities have not achieved any significant effect in ideological and political education. Ideological and political education Cohesion is not strong enough, ideological and political education in colleges and universities to provide qualified personnel training to provide ideological assurance and spiritual motivation, there is still much work to be done. The reasons for this situation are manifold, of which the truth of ideological and political education needs further improvement is an important reason.

As a standard to test whether cognition is correct, it must have the characteristic of linking subjective and objective. Only practice can possess this characteristic. Truth does not have the characteristics of practice, so it can not be used as a criterion to test whether its cognition is correct. In practice, people tend to consciously and unconsciously deconstruct the specific views of some 
classic writers, impart absolute truths to educational objects, and dogmatic the specific views of some classic writers to guide all the work in the colorful real world Encountered many problems, can not explain and explain the problem of mistakes, affecting the quality of ideological and political education in colleges and universities. The truth of the education content of isolation and integration. Just as people often say, not afraid of not knowing the goods, afraid of goods than goods, no comparison there is no identification. This enlightens us: the test of truth is precisely the truth of homogenous things. In the practice of ideological and political education in colleges and universities, they tend to unitize and monopolize the contents of ideological and political education. They circle the content of ideological and political education infused into colleges and universities, and do not appropriately introduce other homogeneous things as reference objects. Opening up is a world trend that is irresistible. Colleges and universities can learn various kinds of information through various channels, including the contents of ideological and political education infused by teachers into colleges and universities and other homogeneous things in the world. The inherent defects in the content of ideological and political education of teachers instilled collide, compare and discriminate with each other in other parts of the world, resulting in the truthfulness and scientificalness of the entire contents of ideological and political education infused by teachers in colleges and universities, Celibacy and credibility decreased to varying degrees, affecting the quality of ideological and political education in colleges and universities.

The truth of educational content is the requirement of the times to improve the quality of ideological and political education. At present, our country's economic and social development has entered a period of structural transformation. The crucial period of development, the period of crucial development and the period of contradictions have been marked. The great practice of socialist modernization has continually raised new and new requirements in ideological and political education, and there is an urgent need for ideological and political education Can assume the important task of the times, advance with the times and serve the socialist modernization. The ideological and political education in colleges and universities is in line with the times and with the modernization. It is an inevitable requirement for higher education put forward by the socialist modernization. It must be noticed that while the ideological and political education in colleges and universities made great achievements, there are also some outstanding problems. In particular, the truth of ideological and political education is somewhat out of place. Resulting in a decrease in coccy and credibility, a decrease in attractiveness and contagion.

Principles refer to the rules and standards on which to speak or act. The principle of ideological and political education reflects the objective laws of ideological and political education throughout the entire process of ideological and political education. In the process of ideological and political education, on the basis of the emotional man, he finally persuaded people by the power of truth. Taking Reason to Serve People is the Essential Requirement of Ideological and Political Education. People-oriented, is the ultimate pursuit of modern ideological and political education and the fundamental idea. Only by implementing the concept of "people first", we can always do a good job in respecting, understanding, caring, motivating and promoting the all-round development of human beings in order to do a good job in ideological and political education in colleges and universities. Respect for people, understand people, care for people, encourage people is the concept of people-oriented ideological and political education in colleges and universities during the practice of the concrete embodiment. To respect and understand people, to care for people and motivators, and finally to rely on the power of truth to realize the fundamental task and ultimate goal of ideological and political education in colleges and universities. No matter how the educational content changes, how to innovate the methods, how the channels are diverse, and how the environment is harmonious, the quality of ideological and political education in colleges and universities must rely on the power of truth to solve the ultimate problem. We must always regard persuading people as the essential requirement of ideological and political education in colleges and universities commence to work. 


\section{The credibility of the contents of ideological and political education in colleges}

During the practice of ideological and political education, such a phenomenon often occurs. The content advocated by ideological and political education is real, truthful, and unbelievable. Some information in the community is false or even harmful, but it makes the educated people believe it. This real alienation that may not be believed in or false does not necessarily make people's suspicions show that the content of ideological and political education is not only truthful, but also requires full demonstration of its credibility on the basis of truth. The credibility of ideological and political education refers to the content of ideological and political education on the basis of truth, the degree of being educated. The credibility of the content of ideological and political education in colleges and universities stems from the process of feedback induction of ideological and political education in colleges and universities. In this process, the acceptance of the contents of ideological and political education by colleges and universities is not passive and passive, and the teachers carry out ideological and political education The content also can not arbitrarily influence the thinking of colleges and universities. Colleges and universities always according to their own level of understanding will be received ideological and political education content filtering, selectively learn what he believes credible content. The truth of the content is the core and soul of ideological and political education in colleges and universities. It is the fundamental principle that must be followed in the practice of ideological and political education in universities. The reason why the credibility of the content of ideological and political education is declining is mainly due to the following reasons: The content of ideological and political education that is not verified by practice is regarded as the content of truth to colleges and universities. With the passage of time and the test of practice, the credibility of the contents of ideological and political education has declined in the hearts of colleges and universities. In the past, , Some of the truthful ideological and political education content often affects the credibility of the preaching content due to the lack of affection between the university and the teachers, the negative influence of the teacher's personality and the limited working level of the teachers With the rapid development of information technology, the diversity of communication media, the diversification of communication channels and the complexity of information sources, some colleges and universities can not use the correct Position, viewpoints and methods to analyze and solve problems; our country is in the community The initial stage of socialism, the trend of economic globalization has become more and more obvious. The complicated information ecological environment affects the normal acceptance of the truthfulness of ideological and political education. The credibility of the ideological and political education in colleges and universities is facing severe challenges.

The credibility of educational content is the source of life in ideological and political education. Vitality is the ability of things to maintain and extend life activities, and is the ability to survive and develop. The truth, goodness and beauty are the primary realms of ideological and political education. The organic unification of the universal realm and the advanced realm forms the organic unity of the amity, feasibility and credibility of ideological and political education. If the impressions of ideological and political education on the educated are not true, good and beautiful, but are fake, evil, ugly, unfriendly, non-believable and unreliable, the educated will dislike the ideological and political education away from the ideological and political education Credibility is the vitality of ideological and political education. The ideological and political education in colleges and universities should be in keeping pace with the times and be synchronized with the modernization. It is an inevitable requirement of higher education for the socialist modernization and also the only way for ideological and political education in colleges and universities to keep pace with the times and improve its quality. If the ideological and political education in colleges and universities loses credibility, it will affect the ideological and political education in colleges and universities, not to mention the quality of ideological and political education to further enhance the healthy growth of colleges and universities, successfully escort, provide ideological assurance and spiritual motivation The task will be difficult to accomplish. The fundamental task of people-oriented and moral education first, teaching and educating people, establishing Lideshu 
people and cultivating builders and successors of the socialist cause will lapse. Specialization, specialization and professionalization are the orientation of teachers in ideological and political education in colleges and universities. Ideological and political education in colleges and universities is a man's work, even the best education content also requires high-quality, high-level teachers to complete the "inculcation." In addition, counselors are an important force in the ideological and political education of teachers in colleges and universities. To measure this team from the professional standards is still relatively weak: the number is not sufficient, the level should be improved, and the stability should be strengthened.

\section{Conclusion}

In the practice of ideological and political education in colleges and universities, there is often a simple truth that no proper effect has been achieved. Colleges and universities are not interested in ideological and political education. They do not like to listen to them, they do not listen to them. They even resist psychologically and resist their actions, Ideological and political education in colleges and universities to reduce the loyalty, the credibility of the decline. Ideological and political education in colleges and universities is not enough truth, but also need to enhance the celibacy and credibility. The power of truth needs the power of emotion, the power of personality and the power of art to give full play to its educational function.

\section{References}

[1] Zhang collar.Innovation of Ideological and Political Education in Colleges and Universities under the Perspective of Weibo [J]. Modern Education Science. 2012 (09)

[2] Liu Zhijun. Publicity and thought in the work of microblogging media guidance [J]. School Party Building and Ideological Education. 2012 (26)

[3] Li Yuan Jing, Li Lin.Weibo: A New Opportunity for the Transformation of Traditional Ideological and Political Education [J] .Helong Higher Education Research 2012,209

[4] Xu Ye. Weibo - Innovative applications that are changing the world [J]. China Science and Technology Forum. 2012 (08)

[5] Zhang Yue. On the counselors microblogging in college ideological and political education work [J]. China Newspaper. 2012 (14)

[6] Li Yuanjing. The status quo and countermeasures of the development of microblogging in universities [J]. People's Forum. 2012 (20)

[7] Liu Xiu-lun, HAO Dong-chao. Analysis of Ideological and Political Education Based on Weibo Carrier [J]. Education Review. 2012 (03) 